\title{
Mengusung Masyarakat Madani melalui Radio Komunitas
}

\author{
DEDE LILIS CH., ${ }^{1}$ NOVA YULIATI, ${ }^{2}$ M.ROCHIM ${ }^{3}$ \\ 1,2,3 Fakultas IImu Komunikasi, Unisba, Jl.Tamansari No.1, Bandung 40116 \\ email: ${ }^{1}$ adelilisubandy@gmail.com, ${ }^{2}$ nova_yuliati@yahoo.com, ${ }^{3}$ mrochim5571@gmail.com
}

\begin{abstract}
This article is about the phenomenon of community radio in Pantura Area, West Java. Radio communities maganed by, for and about the community are rapidly developing among the farmers and fishermen, including in Pantura Area, West Java. The focus of the study is the formation of civil society by standing firmly on communicative actions of Jürgen Habermas. By using qualitative method with case study design, a finding would be produced that community radios implement participatory paradigm and manage community cohesion. We will discuss in details on: (1) initiators of the establishment of community radio; (2) forms of community participation; (3) the financing source of community radio; and (4) the construction of civil society through community radio. This article also covers about how the people see the world of life, that there is social transformation through emancipatordialogs, which then produce community's selfconsciousness as individuals and community members in demanding a domination free communication process. This reality creates the origination of civil society.
\end{abstract}

Keywords: Community Radio, Participatory Paradigm, Civil Society

\begin{abstract}
Abstrak. Artikel ini tentang fenomena radio komunitas di Daerah Pantura Jawa Barat. Radio komunitas yang dikelola oleh, dari, untuk, dan tentang komunitas berkembang pesat di kalangan para petani dan nelayan, termasuk di daerah Pantura Jawa Barat. Fokus kajian ialah pembentukan masyarakat madani dengan berpijak pada tindakan komunikatif Jürgen Habermas. Menggunakan metode kualitatif dengan desain studi kasus, maka dihasilkan temuan bahwa radio komunitas menerapkan paradigma partisipatoris dan mengelola kohesi komunitas. Secara lebih detail didiskusikan tentang: (1) inisiator pendirian radio komunitas; (2) bentuk partisipasi komunitas; (3) sumber pembiayaan radio komunitas; dan (4) konstruksi masyarakat madani melalui radio komunitas. Artikel juga mengulas bagaimana masyarakat memandang dunia kehidupan, sehingga terjadi transformasi sosial melalui dialog emansipatoris, yang kemudian menghasilkan kesadaran diri masyarakat sebagai individu dan anggota masyarakat dalam menuntut proses komunikasi yang bebas dari dominasi. Kenyataan inilah yang melahirkan cikal bakal masyarakat madani.
\end{abstract}

Kata kunci: Radio Komunitas, Paradigma Partisipatoris, Masyarakat Madani.

\section{Pendahuluan}

Seiring perkembangan teknologi informasi dan komunikasi, masyarakat Indonesia yang tersebar di ribuan pulau idealnya memeroleh kemudahan dalam mengakses informasi dan menyuarakan berbagai aspirasi dan persoalannya. Akan tetapi pada kenyataannya, media mainstream yang ada tidak bisa mengelola dan menyediakan seluruh kebutuhan informasi masyarakat, bahkan menurut Direktur Penelitian Asian Media Information dan Communication Centre (AMIC) Kalinga Seneviratne, Ph.D pada 25 Oktober 2010 yang lalu di Jakarta, "Untuk negara kepulauan seperti Indonesia, bahkan lembaga penyiaran publik pun tak mampu menjangkau seluruh masyarakat. Padahal, sejatinya, manusia membutuhkan informasi untuk memberdayakan diri mereka" (website paramadina, 2010).

Tidak bisa dipungkiri bahwa media massa mainstream lebih banyak menomorsatukan peristiwa-peristiwa berskala besar dan nasional ketimbang potret sosial kemasyarakatan yang bersifat lokalit. Fenomena ini kemudian menyadarkan segelintir orang bahwa termarjinalisasinya peristiwa-peristiwa lokal di media massa dalam jangka panjang bisa mengancam kehidupan demokrasi, karena dapat menyumbat aspirasi masyarakat dan tidak terpecahkannya berbagai persoalan lokal 
masyarakat.

Radio sebagai salah satu jenis media massa elektronik telah mengalami perkembangan ke arah kesadaran lokalit ini dengan melahirkan apa yang kemudian dikenal sebagai radio komunitas. Secara sederhana, radio komunitas diartikan sebagai radio dari, oleh, untuk dan tentang komunitas. Radio ini menjadikan komunitas sebagai basis operasionalisasi. Karena menonjolkan unsur komunitas ini pulalah, maka proses produksi dan program acara radio komunitas cenderung berbeda-beda di setiap komunitas, misalnya radio komunitas di desa nelayan berbeda dengan di desa petani, radio komunitas di kota berbeda dengan radio komunitas di desa.

Pada perkembangannya, radio komunitas ini mulai dirasakan memberikan manfaat bagi masyarakat. Kalinga Seneviratne mengatakan, "Radio komunitas dapat memberi informasi yang dibutuhkan oleh komunitasnya, orang-orang yang voiceless (tak mampu menyuarakan kepentingannya)". Lebih lanjut dikatakan bahwa,

Radio komunitas harus bisa menyuarakan orangorang yang tak mampu mengakses mainstream media. Sebagai contoh, radio komunitas dapat memberikan informasi bagi para petani, nelayan, korban bencana alam, perempuan korban kekerasan, ataupun buruh pabrik di daerah terpencil. AMIC, menurut Kalinga, memiliki jaringan radio komunitas untuk memberdayakan para buruh migran dan masyarakat daerah yang berencana bekerja sebagai buruh migran. Radio komunitas juga berperan dalam proses demokrasi karena dapat menyuarakan kondisi masyarakat di tingkat lokal, utamanya yang berhubungan dengan transparansi dan kinerja pemerintah. Selain itu, mereka juga bisa menjadi corong partai politik di tingkat lokal (website paramadina, 2010).

Berdasarkan database Jaringan Radio Komunitas Indonesia (JRKI), saat ini radio komunitas terdapat di 20 provinsi. Data jumlah radio komunitas yang ada di Indonesia per Juni 2007 ialah sebanyak 680 radio komunitas. Provinsi dengan jumlah radio komunitas terbanyak ialah Jawa Barat yakni 348 (Prakoso \& Nugent, 2007 dalam Haryanto \& Ramdojo, 2009: 16). Hal ini menunjukkan bahwa betapa perkembangan jumlah radio komunitas di J awa Barat begitu pesat dibandingkan daerah lainnya. JRKI Jawa Barat sendiri berdiri sejak tahun 2002 dengan 48 radio komunitas. Bahkan, di Jawa Barat ada sejumlah jaringan radio lain, seperti jaringan radio suara petani atau nelayan yang memiliki anggota 280 stasiun radio serta J RKTI yang beranggotakan 30 stasiun radio. Ini artinya, selain dari radio komunitas yang telah terdaftar di KPID, ternyata masih ada radio komunitas petani dan nelayan yang belum menjadi anggota JRKI dengan jumlah yang cukup fantastis. Realitas ini memperlihatkan bahwa betapa antusiasme dan keinginan kuat masyarakat untuk mendirikan radio komunitasnya sendiri.

Menarik untuk menelusuri lebih lanjut, khususnya di daerah Pantura Jawa Barat, karena daerah Pantura merupakan daerah dimana perkembangan radio komunitasnya cukup pesat, misalnya, daerah Cirebon memiliki jaringan radio komunitasnya sendiri yang disebut Jaringan Radio Komunitas Wilayah III Cirebon disingkat Jarik III, sebagaimana dilansir dalam situs Dishubkominfo Kabupaten Indramayu,

Sekarang ini tercatat tidak kurang ada sembilan radio komunitas berdiri di wilayah III Cirebon yang pendiriannya diinisiasi oleh Fahmina Institute. Radio-radio tersebut aktif menyuarakan persoalanpersoalan sosial di tempatnya masing-masing. Menurut Ahmad Rofahan, koordinator Jarik, jaringan ini dimaksudkan sebagai media komunikasi, silaturahmi dan saling belajar dari radio-radio komunitas yang ada di wilayah Cirebon.

Kemudian, Kabupaten Indramayu juga memiliki jumlah radio komunitas yang cukup banyak yakni 29 radio komunitas. Sementara itu di daerah Subang baru 9 radio komunitas.

Pertumbuhan kuantitas radio komunitas ini, jelas tidak hanya sekadar radio komunitas didirikan saja, tetapi bagaimana kemudian radio komunitas bisa tetap beroperasi dan tidak gulung tikar di tengah jalan. Hal ini dikarenakan radio komunitas sama sekali tidak berorientasi komersial melainkan bersifat kesukarelaan dari komunitas masyarakatnya sendiri. Artinya harus ada sebuah kekuatan yang bisa terus menggerakkan masyarakat untuk tetap menghidupkan radio komunitasnya. Berbicara tentang sejauh mana kekuatan itu terbangun dalam masyarakat bisa ditelusuri dari bagaimana dorongan masyarakat terhadap keberlangsungan radio komunitas serta apa saja bentuk dukungan masyarakat juga bagaimana kemudian semangat kebersamaan masyarakat untuk tetap memertahankan radio komunitasnya. Oleh karena itu, kajian ini mencoba menelusuri lebih lanjut dengan memfokuskan pada persoalan siapa sajakah para inisiator pendiri radio komunitas? bagaimana bentuk partisipasi masyarakat terhadap radio komunitas? bagaimana sumber pembiayaan radio komunitas? Serta bagaimana radio komunitas membentuk masyarakat madani?

Fenomena radio komunitas digali dengan menggunakan perangkat metode kualitatif dengan pendekatan studi kasus. Metode penelitian kualitatif digunakan, karena "lebih dimaksudkan untuk memberikan gambaran (description) dan pemahaman (understanding) mengenai bagaimana dan mengapa gejala atau realitas sosial terjadi atau berkembang dan tidak dimaksudkan untuk memberikan penjelasan, mengontrol, dan memprediksi gejala-gejala" (Pawito, 2007: 35 
dalam Pawito \& Kartono, 2013: 114). Sementara itu, studi kasus menurut Patton (2002: 477):

merupakan upaya mengumpulkan, kemudian mengorganisasikan, dan menganalisis data tentang kasus-kasus tertentu berkenaan subjek yang diteliti dengan tetap berpegang pada prinsip holistik, interpretif, dan kontekstual (Pawito \& Kartono, 2013: 114).

Karakteristik utama yang mencirikan penelitian studi kasus menurut Hatch (2002) ialah pertama, meskipun penelitian studi kasus terkadang difokuskan pada representasi individu dari suatu kelompok, tetapi lebih sering ditujukan pada suatu fenomena. Kedua, fenomenon yang diteliti dalam konteks alamiah berdasarkan pada ruang dan waktu. Ketiga, penelitian studi kasus merupakan suatu deskripsi yang kaya, karena didasarkan pada kedalaman dan keragaman sumber informasi untuk menciptakan mental image yang menggambarkan kompleksitas kehidupan tentang beragam variabel yang inheren dalam fenomenon yang diteliti (Hancock \& Algozzine, 2006: 15-16).

Penelitian studi kasus, karenanya harus memuat ketiga hal tersebut. Dalam ungkapan Miller (1996: 167), studi kasus ialah in-depth analyses of single or few communities, organizations, or person's lives, they involved detailed and often subtle understandings of the social organization of everyday life and person's live experience (Pawito \& Kartono, 2013: 114). Oleh karena itu, data dihimpun dari berbagai sumber, yakni wawancara langsung dengan para penggiat radio komunitas di daerah Pantura, kemudian observasi, dan studi dokumen. Key informan terdiri dari kepala siaran, ketua radio komunitas, para penyiar, hingga koordinator radio komunitas wilayah III Jarik Cirebon. Berikut daftar nama radio komunitas di daerah Pantura Jawa Barat yang dikaji dalam artikel ini ada pada Tabel 1.

\section{I nisiator Pendirian Radio Komunitas}

Para inisiator berdirinya radio komunitas di daerah Pantura Jawa Barat sebagian besar ialah para anak muda di daerah tersebut. Para inisiator ini memiliki karakteristik yang khas dibandingkan anggota masyarakat yang lain, yakni mereka yang memiliki karakter berikut: (1) memiliki hubungan yang luas, baik dengan pihak pimpinan desa maupun dengan masyarakat; (2) memiliki kemauan untuk memajukan masyarakatnya; (3) memiliki jiwa kesukarelaan atau volunterisme untuk masyarakat; dan (4) memiliki ide dan kemauan untuk melakukan sesuatu bagi masyarakat. Dengan demikian, para inisiator ini ialah orang-orang yang memiliki kecerdasan sosial untuk terus meningkatkan kualitas hidup masyarakatnya. Karenanya mereka merupakan para pelaku aktif dalam pembangunan di desanya.

Dalam proses pendirian radio komunitas sendiri, para inisiator melakukannya berdasarkan pada dorongan (drive) yang berbeda-beda, namun kesemuanya lebih didasarkan pada dorongan eksternal dari pihak masyarakat. Adapun dorongan berdirinya radio komunitas tersebut diklasifikasikan ke dalam 3 kategori, yakni: Pertama, Mendirikan radio komunitas atas inisiatif dan kesadaran diri sendiri yang kemudian idenya dikomunikasikan pada anggota masyarakat yang lain agar mendapatkan masukan dan dukungan.

Kedua, Mendirikan radio komunitas atas inisiatif masyarakat karena mereka menginginkan media komunitasnya sendiri untuk mendapatkan informasi dan hiburan yang sesuai dengan kebutuhan mereka, akan tetapi pengelolaannya diserahkan kepada seorang anggota masyarakat yang dianggap memiliki kompetensi untuk mengelola radio komunitas karena faktor memiliki pengalaman dalam bidang penyiaran radio.

Ketiga, Mendirikan radio komunitas karena inisiatif komunitas dan dikelola oleh komunitas juga. Ide awalnya memang berasal dari segelintir anak muda, kemudian disampaikan pada masyarakat dan mendapatkan dukungan dari masyarakat. Selain itu juga, anak muda ini diserahi tanggung jawab untuk mengelola radio komunitas, karena masyarakat menganggap mereka mampu dan ketua rakom ditentukan berdasarkan hasil rembukan masyarakat. Untuk memperjelas posisi para inisitor pendirian radio komunitas di daerah Pantura yang selanjutnya juga menjadi pengelola radio komunitas, maka dibuatlah model inisiator berikut pada gambar 1 .

Tabel 1

Radio Komunitas yang Dikaji

\begin{tabular}{|cll|}
\hline No. & Nama Radio Komunitas & \multicolumn{1}{c|}{ Alamat } \\
\hline 1. & Monalisa & Jl. Raya Kasomalang Kulon no. 9, Kasomalang Kulon, Subang \\
2. & Arya FM & Jl. Pramugari Blok Kebon I, Eretan Kulon, Kandanghaur, Indramayu \\
3. & QLan FM & Jl. Kiyanti RT.15/04 Klayan, Gunung Djati, Cirebon \\
4. & NHfm & KM. 4 Telagasari RT. 05/02, Pasir Mukti, Telagasari, Karawang \\
\hline
\end{tabular}




\section{Bentuk Partisipasi Masyarakat terhadap Radio Komunitas}

Setelah radio komunitas berdiri di daerah Pantura, masyarakat tidak tinggal diam, melainkan mereka berupaya agar radionya tersebut dapat terus mengudara dan menyiarkan berbagai program acara yang mereka sukai. Upaya ini memang tidak berjalan mulus, melainkan secara pasang surut, kadang menguat, kadang melemah. Tetapi, masyarakat tetap bisa memertahankan keberadaan radio komunitasnya, karena keberlangsungan sebuah radio komunitas benarbenar bergantung pada keterlibatan masyarakatnya. Girard mengatakan, "karakteristik umum dari radio komunitas ialah berbasis masyarakat, independen, dan partisipatoris" (Abda, 2008: 7). Keberadaan dan keberlangsungan radio komunitas di daerah Pantura tersebut walhasil memunculkan berbagai bentuk partisipasi masyarakat. Bentuk partisipasi ini dilihat dari tiga sudut pandang, yakni: (1) motif masyarakat berpartisipasi; (2) partisipasi masyarakat dalam pembiayaan radio komunitas; dan (3) partisipasi masyarakat dalam proses siaran radio komunitas.

Kebutuhan masyarakat akan kehadiran radio komunitas berbeda-beda pada setiap orang dan pada setiap kelompok masyarakat. Hal ini tentu saja dikarenakan berbagai latar masyarakat yang berbeda-beda pula. Oleh karena itu, motif kebutuhan menjadi dasar pijakan dan di daerah Pantura terdapat 5 (lima) klasifikasi motif kebutuhan masyarakat terhadap radio komunitas, yakni: (1) menjadikan radio komunitas sebagai sarana silaturahim; (2) menjadikan radio komunitas sebagai sarana informasi; (3) menjadikan radio komunitas sebagai media penyaluran hobi; (4) menjadikan radio komunitas sebagai sarana hiburan; serta (5) menjadikan radio komunitas sebagai sarana berdakwah.
Motif menjadi pijakan awal yang penting dan berdampak luar biasa untuk melahirkan sebuah radio komunitas, karena radio ini bukanlah radio komersial yang ditujukan untuk mendapatkan profit, tetapi murni bersifat sukarela, sehingga motif masyarakat terhadap radio komunitas menjadi kapital sosial yang sangat mendasar. Motif ini menjadi langkah pertama pendirian radio komunitas, apakah akan berdiri atau tidak? apakah akan terus berjalan atau berhenti?

Motif yang tumbuh di kalangan penggiat radio komunitas dan masyarakatnya dengan mendirikan dan mengelola radio komunitas untuk mencapai tujuan mereka bersama menjadi pertanda bahwa manusia itu ialah kreator. Manusia menjadi subjek yang bisa menciptakan dan melahirkan sesuatu, serta manusia mampu mempengaruhi dan mengubah lingkungan sosialnya. Mengapa manusia berkreasi melahirkan radio komunitas di daerahnya masing-masing? J uga berasal dari bagaimana manusia itu sendiri memandang dirinya dan kehidupannya. Termarjinalisasinya masyarakat dalam wacana media mainstream dan keterkungkungan mereka dalam memenuhi kebutuhan pada media, membuat masyarakat ingin membebaskan diri, mencari alternatif, hingga melahirkan medianya sendiri. Akan tetapi, untuk terus berjalan radio komunitas tidak bisa hanya sekadar bersandar pada adanya motif saja, melainkan juga salah satunya ialah adanya dukungan pembiayaan dari masyarakat. Pada masyarakat Pantura partisipasi dalam hal pembiayaan ini berjalan. Adapun bentuk partisipasi masyarakat dalam pembiayaan radio komunitas, berupa: (1) iuran komunitas yang bersifat rutin bulanan dan insidental, misalnya melalui arisan fans, pengajian fans, dan permintaan lagu; (2) sumbangan dari para pengelola, seperti dana, alat siaran, makanan dan

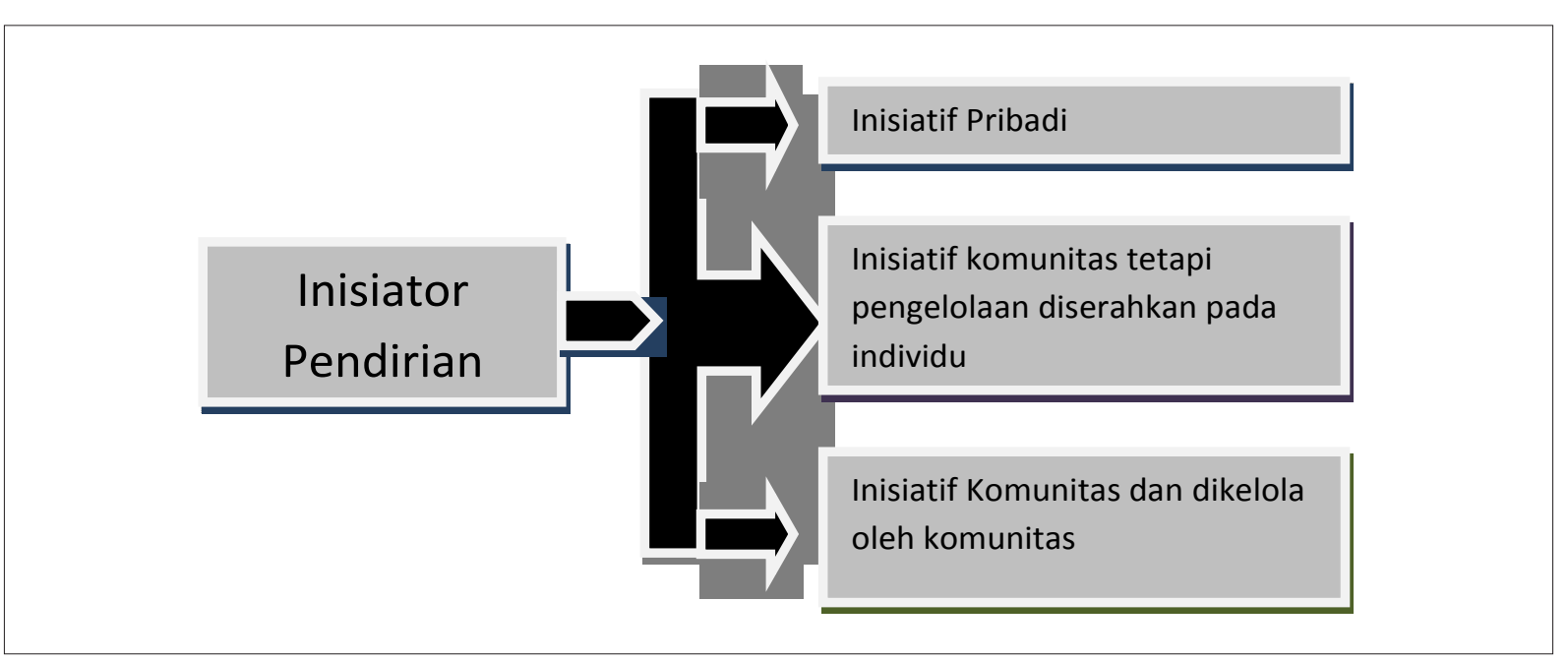

Gambar 1

Model Inisiator Pendirian Radio Komunitas 
minuman; dan (3) iklan layanan masyarakat (ILM) yang biasanya dilakukan oleh para pedagang lokal yang ingin mempromosikan barang dagangannya dengan cara dibuatkan ILM oleh pengelola radio.

Adapun biaya ILM ini ada yang ditentukan oleh pihak radio komunitas dengan tarif yang sangat murah atau tarif bayaran secara sukarela dari masyarakat yang memasang ILM. Adapun iklan layanan ini disiarkan sepuasnya karena berulang kali dalam sehari dan dalam jangka waktu yang cukup lama.

Selain berpartisipasi dalam hal pembiayaan, masyarakat juga berpartisipasi dalam proses siaran radio komunitas, yakni sebagai: (1) pendengar pasif, yakni masyarakat yang sangat jarang melakukan interaksi dengan pihak radio komunitas, baik pada kegiatan on-air maupun offair, (2) pendengar aktif, yakni masyarakat yang sering berinteraksi dan memberikan respon berupa permintaan dan saran kepada pihak radio komunitas, baik pada kegiatan on-air maupun offair, dan (3) pengelola dan penyiar, yakni menjadi pengelola dan atau penyiar radio komunitas dengan didasarkan pada jiwa voluntarisme, karena radio komunitas tidak memberikan keuntungan finansial pada mereka dan memang faktor finansial tidak menjadi orientasi keterlibatan mereka di radio komunitas. Mereka lebih memiliki orientasi yang melampaui persoalan profit (beyond profit) khususnya untuk pribadi, karena mereka lebih berorientasi mengedepankan kepentingan bersama dengan masyarakat dan mencoba memenuhi kebutuhan masyarakat terhadap radio komunitas.
Partisipasi masyarakat yang sukarela juga karena mereka sendiri merasakan manfaat dari keberadaan radio komunitasnya, sebagaimana dipaparkan dalam buku panduan radio komunitas yang diterbitkan oleh UNESCO (2001) bahwa,

radio komunitas berusaha untuk membuat pendengar sebagai 'protagonis' (tokoh utama), melalui keterlibatan mereka dalam seluruh aspek dari manajemen dan produksi programnya, dan dengan menyajikan kepada mereka program yang akan membantu mereka dalam pembangunan dan kemajuan sosial di komunitas mereka" (Fraser dan Estrada 2001: 15, dalam Jurriens, 2003: 118).

Ini artinya, apa yang sudah dilakukan oleh masyarakat Pantura dengan berbagai bentuk partisipasinya menghidupi radio komunitas menunjukkan keinginan kuat mereka untuk membangun dan memajukan komunitasnya.

Berbagai bentuk partisipasi inipun akhirnya memunculkan model partisipasi masyarakat Pantura terhadap radio komunitasnya, sebagaimana pada gambar 2 .

\section{Sumber Pembiayaan Radio Komunitas Daerah Pantura}

Dalam pembiayaan radio komunitas terdapat beberapa sumber pendapatan yang kemudian dimanfaatkan oleh pengelola radio komunitas sebagai biaya operasionalisasi siaran, terutama untuk biaya listrik selama proses siaran radio komunitas. Sementara itu, untuk para pengelola dan penyiar radio komunitas sendiri tidak ada insentif. Mereka mengelola radio komunitas

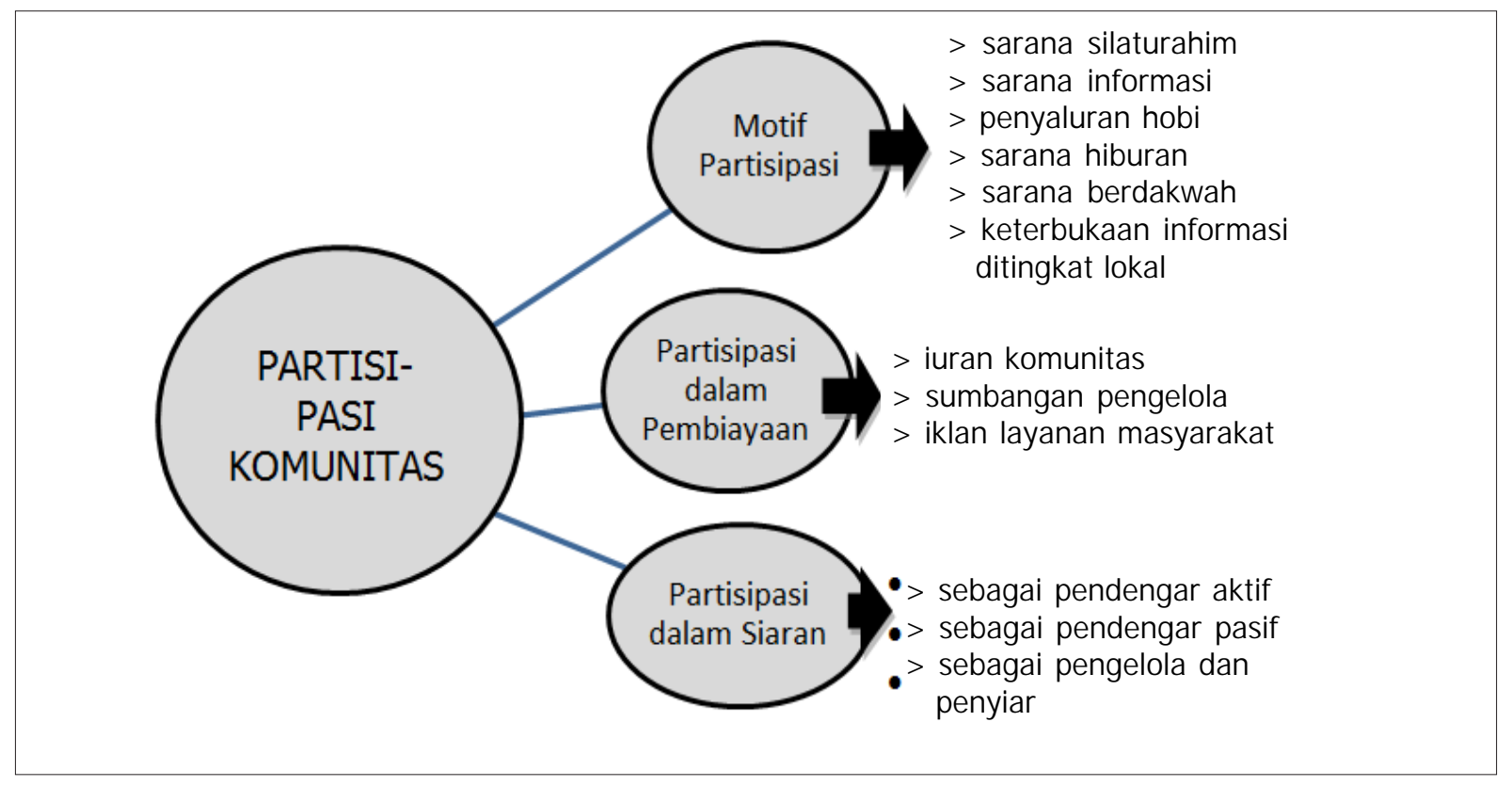

Gambar 2

Model Partisipasi Komunitas

Sumber Pembiayaan Radio Komunitas Daerah Pantura 
tanpa berorientasi profit pribadi, melainkan hanya didasarkan pada jiwa voluntarisme belaka. Oleh karena itu, mereka tidak berpenghidupan dari radio komunitas, melainkan memiliki mata pencaharian dalam bidang lainnya.

Adapun pembiayaan radio komunitas di daerah Pantura diperoleh dari 5 (lima) sumber, yakni: (1) iuran komunitas; (2) sumbangan pengelola; (3) iklan layanan masyarakat; (4) bantuan pemerintah desa; dan (5) sponsorship dari lembaga lain. Sebagaimana diilustrasikan dalam gambar 3 .

\section{Radio Komunitas Melahirkan Cikal Bakal Masyarakat Madani}

Istilah komunitas berkaitan dengan banyak fenomena, pola penafsiran dan juga asosiasi. Sejumlah ilmuwan lebih suka membatasi istilah komunitas pada ukuran tertentu di mana "penduduk dan anggotanya terlibat dalam hubungan yang cukup akrab dalam kehidupan sehari-hari. Hubungan keakraban itu sendiri ditandai dengan sikap dan perilaku saling mengenal" (Azarya, 2000: 146). Kemudian menurut Warren, ada beberapa fungsi yang dimiliki oleh sebuah komunitas, salah satunya ialah, "pengaturan tentang pemenuhan kebutuhan-kebutuhan ekonomi dasar, sosialisasi, kontrol sosial, partisipasi sosial, dan perilaku saling mendukung" (Azarya, 2000: 146).

Radio komunitas merupakan salah satu media yang berkembang dalam komunitas. "Radio komunitas merupakan salah satu saluran dan media sosialisasi yang efektif terutama dalam komunitas yang terbatas serta bersifat lokal; termasuk dalam menjalankan fungsinya untuk menyebarluaskan nilai dan norma tertentu"
(Rachmiatie, Sidik \& Parihat, 2007: 123). Radio komunitas karenanya memiliki karakteristik yang khas dibandingkan dengan radio komersial pada umumnya.

Dalam UU No. 32/2002 radio komunitas disebut juga lembaga penyiaran komunitas yang berdasarkan pada Pasal 21 ayat 1 memiliki ciriciri: Lembaga penyiaran berbadan hukum Indonesia; Bersifat independen; Tidak komersial; Berdaya pancar rendah; Daya jangkauan wilayah terbatas; Hanya melayani kepentingan komunitasnya saja.

Selanjutnya fungsi utama radio komunitas secara lebih luas yakni sebagai:

(1) merepresentasikan, mendukung budaya dan identitas lokal; (2) menciptakan berbagai pendapat dan opini di udara; (3) menyediakan varietas program acara; (4) mendorong demokrasi dan dialog terbuka; (5) mendukung pembangunan dan perubahan sosial; (6) memproduksi civil society; (7) mengedepankan ide tentang good governance; (8) mendorong partisipasi melalui membagi informasi dan inovasi; (9) memberikan suara kepada mereka yang tidak memiliki suara; (10) menyediakan pelayanan sosial sebagai pengganti telepon; (11) menyumbangkan pada keberagaman dalam kepemilikan siaran; (12) mengembangkan sumber daya manusia untuk industri siaran (J urriëns, 2003: 118).

Jika konsep ideal radio secara keumuman ialah berfungsi sebagai medium interaktif, tempat pendengar dapat mempengaruhi kepemilikan, manajemen, dan produksi program, maka pada radio komunitas pendengar tidak hanya sekadar mempengaruhi saja, melainkan terlibat dalam penatakelolaan hingga konten siaran, sebagaimana diungkapkan oleh Edwin Jurriëns, "radio komunitas memberikan pendengarnya kesadaran diri bukan

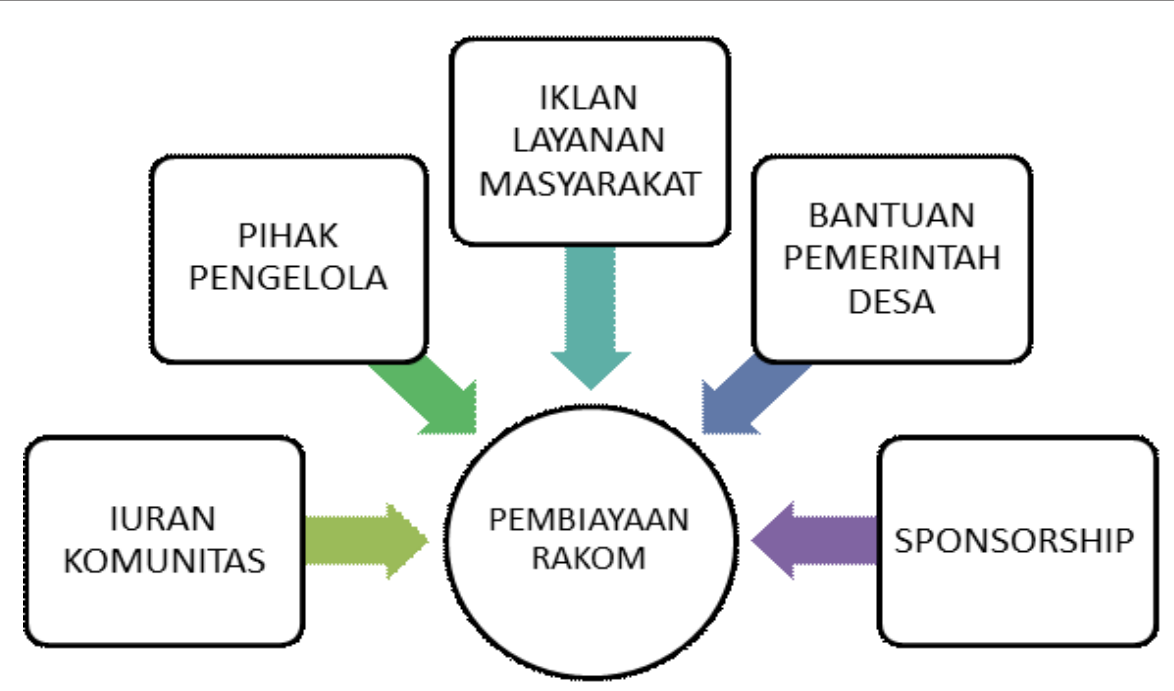

Gambar 3

Model Pembiayaan Radio Komunitas 
saja melalui keikutsertaan mereka dalam manajemen dan produksi, tapi juga melalui isi acaranya" (Jurriëns, 2003:120).

Kesadaran diri masyarakat inilah yang nampak menonjol dan menjadi basis kapital sosial dari sebuah masyarakat untuk terus menerus berusaha menghidupkan radio komunitasnya. Dengan adanya kesadaran diri, maka muncul keinginan masyarakat untuk memiliki medianya sendiri dalam bentuk radio komunitas yang bisa diharapkan mampu memenuhi kebutuhan informasi, hiburan dan mengangkat isu-isu sosial kemasyarakatan yang bersentuhan langsung dengan kehidupan riil keseharian mereka. Mereka ingin memiliki media yang dekat dengan realitas kehidupannya, memenuhi kebutuhan mereka atas media, serta mendengarkan suaranya.

Oleh karena itu, Carlos Arnaldo yang dikutip oleh Bruce Girard mengatakan, "Radio komunitas adalah suatu proses sosial atau peristiwa di mana warga komunitas berkumpul bersama untuk merancang program dan memproduksinya dan mengudarakannya, kemudian mengambil peran utama bagi nasib mereka sendiri" (Abda, 2008: 12). Artinya, masyarakat sebagai aktor yang aktif terlibat dalam proses operasionalisasi radio komunitas. Ini menunjukkan adanya partisipasi masyarakat. "Partisipasi merupakan keterlibatan atau keikutserataan secara aktif seseorang baik individu maupun secara kelompok masyarakat dalam aktivitas kegiatan dengan menggerakkan semua sumber daya, pengetahuan, keterampilan dan tenaga guna mencapai tujuan pembangunan yang diharapkan" (Mulyawan, 2012: 161).

Gagasan ini sejalan dengan pemahaman para pemikir budaya yang melahirkan paradigma pembangunan partisipatif atau dikenal dengan Participatory Paradigm atau Multiplicity Paradigm (Abda, 2008: 7). Menurut paradigma ini setiap bangsa harus memiliki proses pembangunannya sendiri, yang berbeda dan tidak meniru dari bangsa lain, karena setiap bangsa berbeda karakter dan persoalan, sehingga memang tidak ada model pembangunan yang bersifat universal dan berlaku di semua bangsa. Secara tegas dinyatakan oleh Servaes (1999),

There is no universal development model, that development is an integral multidimensional, and dialectical process that can differ from society to society (Abda, 2008: 8).

Paradigma ini melihat bahwa pembangunan ialah sebuah proses yang multidimensional dan dialektikal, sehingga aspek ekonomi, sosial, dan budaya menjadi aspek yang sama pentingnya dalam pembangunan.

Dialektika itu diejawantahkan oleh masyarakat Pantura melalui berbagai bentuk partisipasi mereka, karena "partisipasi memungkinkan masyarakat untuk memberdayakan dirinya sendiri dalam membuat perubahan, menciptakan kemandirian mereka untuk menemukan masalah dan merencanakan aksi kolektif untuk memecahkan bersama masalah yang mereka hadapi" (Abda, 2008:8). Dengan paradigma partisipatoris inilah, maka radio komunitas berperan penting dalam mempercepat perubahan sosial berbasis masyarakat dengan menyediakan akses, merangsang partisipasi dan menghargai hak masyarakat untuk memeroleh informasi dan berkomunikasi secara terbuka.

Berbicara tentang keterbukaan komunikasi, tentu didasarkan pada suatu proses komunikasi yang tanpa dominasi, karena semua pihak memberikan peluang pada setiap orang untuk ikut berbicara dan mengungkapkan pendapatnya. Agaknya kesadaran masyarakat Pantura yang didukung oleh karakter masyarakat pesisir yang bersifat egaliter, terbuka, dan blak-blakan dalam berkomunikasi membuat ruang kesadaran tersebut menjadi lebih mudah berkembang ketimbang pada masyarakat di daerah lainnya. Fenomena ini relevan dengan pemikiran Jürgen Habermas tentang Tindakan Komunikatif. Habermas menjelaskan bahwa masyarakat bukan sekadar sebuah sistem pengendalian diri, melainkan juga suatu dunia kehidupan, sebuah dunia yang dihayati yang tersusun dari subjek-subjek yang bertindak dan berbicara melalui medium simbol-simbol. Menurutnya masih ada tempat di mana manusia dapat mengalami ide kebebasan, sehingga selalu masih ada tempat berpijak untuk menentang penindasan. Tempat itu adalah faktor adanya komunikasi. Habermas memperlihatkan bahwa komunikasi tidak mungkin tanpa adanya kebebasan. Dalam pengalaman komunikasi karenanya sudah tertanam pengalaman kebebasan. Gagasan orisinal Habermas tentang transformasi sosial menurutnya perlu diperjuangkan melalui dialog-dialog emansipatoris (Hardiman, 2009: 32). Dan itu dilakukan hanya melalui 'jalan komunikasi' dan bukan melalui 'jalan dominasi'. Inilah yang akan diutopikan terwujudnya suatu masyarakat demokratis radikal, yaitu masyarakat yang berinteraksi dalam suasana 'komunikasi bebas dari penguasaan'.

Habermas percaya bahwa konsep tindakan komunikatif memberi skema yang konseptual di mana seseorang dapat mendiagnosa penyakit dalam 'dunia kehidupan' dan memberikan penyembuhan. Habermas juga percaya bahwa tindakan komunikatif memungkinkan adanya perlindungan terhadap nilai-nilai modern dari rasional sosial, konsensus, emansipasi, dan solidaritas sehingga memberikan dasar bagi kritik dan rekonstruksi sosial. Ini artinya, masyarakat Pantura telah mulai mengalami kebebasan berkomunikasi melalui eksistensi radio komunitasnya, memungkinkan masyarakat untuk 
bisa menemukan persoalan-persoalan kehidupan bermasyarakatnya dan berupaya untuk mengatasi persoalan-persoalan tersebut secara lebih mandiri. Hal ini jelas suatu iklim yang kondusif untuk memajukan dan mengembangkan komunitas.

Dalam konteks kebijakan publik, frasa pengembangan komunitas biasanya digunakan untuk menyebut proyek-proyek pengembangan suatu daerah yang menyertakan keterlibatan aktif para penduduknya. Awalnya konsepsi pengembangan komunitas ini diterapkan oleh pemerintah kolonial Inggris, Perancis, dan Belgia di Afrika dan Asia, khususnya seusai Perang Dunia Kedua, melalui strategi-strategi sosial, ekonomi dan politik, dengan prioritas pada kawasankawasan pedesaan. Pada tahun 1960-an, istilah pengembangan komunitas digunakan untuk menyebut berbagai proyek di daerah perkotaan di Amerika dan juga Inggris, di mana kemiskinan dan juga berbagai penyakit sosial terkumpul. Pengembangan komunitas dalam konteks ini, "dimaksudkan untuk mencari solusi-solusi yang murah dan efektif guna menanggulangi berbagai masalah melalui pembangkitan kesadaran dan daya kreasi penduduk setempat sehingga mereka mau dan mampu mencari cara-cara untuk memecahkan persoalan mereka sendiri" (Marris, 2000: 149).

Fungsi untuk pengembangan komunitas inilah yang dilakukan oleh radio komunitas. Bianca Miglioretto (2007) menegaskan,

Penggunaan rakom adalah suatu piranti komunikasi yang baru dan merupakan sesuatu yang potensial dalam menyukseskan pembangunan desa-kota dan merupakan sebuah strategi untuk membantu warga menempatkan komunitas pada posisi yang lebih baik dalam menerapkan proyek pembangunan, membantu mata pencahariannya dan memberdayakan warga untuk memerbaiki kehidupannya, memberikan dasar kepada komunitas untuk berdiskusi dan membicarakan strategi pembangunan juga pemerintah lokal untuk menginformasikan kepada warga mengenai program-program baru dalam konteks lokal (Hakam, 2011: 73).

Hal ini sejalan dengan konsep masyarakat sipil atau masyarakat madani (civil society) yang merupakan konsep lama dalam pemikiran sosial dan politik yang belakangan ini bangkit kembali. Secara tradisional, tepatnya sampai abad ke-18, istilah civil society kurang lebih sekadar terjemahan istilah Romawi societas civilis, atau istilah Yunani koinonia politike. Istilah tersebut sinonim dengan "masyarakat politik". Ketika Locke berbicara tentang "pemerintahan politik", atau ketika Kant berbicara tentang burgerliche gesellschaft, atau tatkala Rousseau membahas etat civil, mereka samasama bicara tentang dunia politik, yang dalam istilah Yunani biasa disebut polis. Karenanya menurut Kumar, masyarakat madani merupkan arena bagi warga negara yang aktif secara politik. I stilah tersebut juga berkonotasi bahwa orang-orang yang terlibat di dalamnya adalah bagian dari masyarakat beradab yang mendasarkan hubungan-hubungannya pada suatu sistem hukum, bukannya pada tatanan hukum otokratis yang korup (Kumar, 2000: 114).

Kemudian, ada perkembangan baru pada paruh abad ke-18 yang memutuskan persamaan historis antara masyarakat madani dengan konsep kenegaraan. Hal itu sangat dipengaruhi oleh pemikiran sosial Inggris. Dalam tulisan-tulisan J ohn Locke, Tom Paine, Adam Smith dan Adam Ferguson, terdapat gagasan yang menyatakan bahwa "masyarakat itu sesungguhnya terpisah dari negara, dan bahwa masyarakat memiliki bentuk dan prinsip-prinsipnya sendiri" (Kumar, 2000: 114). Selanjutnya, Hegel berjasa mengembangkan makna modern dari konsep masyarakat madani. Dalam bukunya berjudul Philosophy of Right (1958) dia mengatakan, "masyarakat sipil adalah wadah kehidupan etis yang terletak di antara kehidupan keluarga dan kehidupan kewarganegaraan" (Kumar, 2000: 114). Sebagaimana para ekonom Inggris, Hegel melihat kandungan masyarakat madani terutama ditentukan oleh permainan bebas kekuatan ekonomi dan pencarian jati diri individual. Namun masyarakat madani juga mencakup lembaga-lembaga sosial dan kenegaraan yag mewadahi dan mengatur kehidupan ekonomi, yang selanjutnya memicu proses pendidikan bagi gagasan kehidupan kenegaraan secara rasional. Jadi kekhasan masyarakat madani telah melampaui universalitas negara.

Berikutnya, Antonio Gramsci dalam kumpulan tulisannya yang berjudul Prison Notebooks (1971), mencoba menyelamatkan konsep masyarakat madani di awal abad ke-20. Ia kembali pada gagasan Hegel, bahkan beranjak lebih jauh dari Hegel dengan memisahkan makna masyarakat madani dari ekonomi dan semata-mata mengaitkannya dengan negara. Masyarakat madani dinyatakan sebagai "bagian dari negara yang terlepas dari pemaksaan atau aturan-aturan formal, meski tetap mengandung unsur rekayasa seperti lazimnya institusi politik" (Kumar, 2000: 114). Konsep tersebut juga diartikan sebagai wadah "politik budaya". Adapun lembaga-lembaga masyarakat madani itu adalah institusi keagamaan (masjid, pesantren, gereja), sekolah, serikat pekerja, dan berbagai organisasi lainnya. Di samping itu, masyarakat madani juga merupakan arena di mana hegemoni penguasa dapat ditentang atau digoyahkan secara sah. Konsep masyarakat madani dari Gramsci inilah yang sangat disukai, khususnya oleh mereka yang mencoba menentang struktur penguasa di masyarakat tanpa melalui konfrontasi politik langsung, karena mereka lebih memilih perang 
saraf budaya secara bergerilya. Kebudayaan dan pendidikan merupakan lahan di mana hegemoni itu dapat ditentang dan diakhiri.

Konsep masyarakat madani ini yang kemudian dalam pandangan penulis merupakan salah satu substansi hadirnya radio komunitas dalam masyarakat Pantura, karena menunjang penciptaan institusi konkret yang diperlukan oleh masyarakat untuk mencapai tujuan bersama dan mencoba mengkritisi penguasa di tingkat desa tanpa konfrontasi langsung serta membuat masyarakat belajar mengatasi persoalan kehidupannya secara mandiri dengan tidak bergantung terus kepada pemerintah. Dan itu semua dilakukan masyarakat Pantura dengan melahirkan dan memerjuangkan keberlangsungan radio komunitas di tengah-tengah kehidupan mereka.

\section{Simpulan dan Saran}

Ketidakterwakilan kebutuhan dan termarjinalisasinya masyarakat dalam ruang media massa mainstream menjadi dorongan (drive) yang kuat pada mereka untuk memiliki medianya sendiri. Diawali oleh ide segelintir orang yang peduli dengan kondisi masyarakatnya, lahirlah gagasan untuk mendirikan radio komunitas di daerah Pantura Jawa Barat. Inisiasi pendirian radio komunitas tersebut diklasifikasikan ke dalam 3 kategori, yakni: (1) Mendirikan radio komunitas atas inisiatif dan kesadaran diri sendiri yang kemudian idenya dikomunikasikan pada anggota masyarakat yang lain agar mendapatkan masukan dan dukungan; (2) Mendirikan radio komunitas atas inisiatif masyarakat karena mereka menginginkan media komunitasnya sendiri untuk mendapatkan informasi dan hiburan yang sesuai dengan kebutuhan mereka, akan tetapi pengelolaannya diserahkan kepada seorang anggota masyarakat yang dianggap memiliki kompetensi untuk mengelola radio komunitas karena faktor memiliki pengalaman dalam bidang penyiaran radio; serta (3) Mendirikan radio komunitas karena inisiatif komunitas dan dikelola oleh komunitas juga. Ide awalnya memang berasal dari segelintir anak muda, kemudian disampaikan pada masyarakat dan mendapatkan dukungan dari masyarakat. Selain itu juga, anak muda ini diserahi tanggung jawab untuk mengelola radio komunitas, karena masyarakat menganggap mereka mampu dan ketua rakom ditentukan berdasarkan hasil rembukan masyarakat.

Pendirian radio komunitas sangat dipengaruhi oleh motif yang mendasarinya. Adapun motif berdirinya radio komunitas di daerah Pantura diklasifikasikan ke dalam 5 jenis, yakni: (1) menjadikan radio komunitas sebagai sarana silaturahim; (2) menjadikan radio komunitas sebagai sarana informasi; (3) menjadikan radio komunitas sebagai media penyaluran hobi; (4) menjadikan radio komunitas sebagai sarana hiburan; serta (5) menjadikan radio komunitas sebagai sarana berdakwah.

Akan tetapi, untuk terus berjalan radio komunitas tidak bisa hanya sekadar bersandar pada adanya motif saja, melainkan juga harus ada dukungan masyarakat. Partisipasi masyarakat di daerah Pantura terhadap radio komunitas meliputi 2 bentuk, yakni partisipasi dalam pembiayaan dan partisipasi dalam proses siaran. Bentuk partisipasi masyarakat dalam pembiayaan berupa: (1) iuran komunitas yang bersifat rutin bulanan dan incidental, misalnya melalui arisan fans, pengajian fans, dan permintaan lagu; (2) sumbangan dari para pengelola, seperti dana, alat siaran, makanan dan minuman; dan (3) iklan layanan masyarakat (ILM) yang biasanya dilakukan oleh para pedagang lokal yang ingin mempromosikan barang dagangannya dengan cara dibuatkan ILM oleh pengelola radio.

Sementara itu, bentuk partisipasi dalam proses siaran, yakni sebagai: (1) pendengar pasif, yakni masyarakat yang sangat jarang melakukan interaksi dengan pihak radio komunitas, baik pada kegiatan "on-air" maupun "off-air"; (2) pendengar aktif, yakni masyarakat yang sering berinteraksi dan memberikan respon berupa permintaan dan saran kepada pihak radio komunitas, baik pada kegiatan "on-air" maupun "off-air"; dan (3) pengelola dan penyiar, yakni menjadi pengelola dan atau penyiar radio komunitas dengan didasarkan pada jiwa voluntarisme, karena radio komunitas tidak memberikan keuntungan finansial dan mereka juga tidak menjadikan faktor finansial sebagai orientasi keterlibatannya di radio komunitas.

Adapun pembiayaan radio komunitas di daerah Pantura diperoleh dari lima sumber, yakni iuran komunitas, sumbangan pengelola, iklan layanan masyarakat, bantuan pemerintah desa, dan sponsorship dari lembaga lain.

Masyarakat Pantura melalui radio komunitasnya telah menerapkan paradigma partisipatoris dengan menjadikan radio komunitas untuk mempercepat perubahan sosial berbasis masyarakat dengan menyediakan akses, merangsang partisipasi dan menghargai hak masyarakat untuk memeroleh informasi dan berkomunikasi secara terbuka. Mereka telah melakukan Tindakan Komunikatif dengan memberikan kebebasan dan menentang penindasan dalam berkomunikasi. Oleh karenanya, hegemoni penguasa dapat ditentang atau digoyahkan tanpa melalui konfrontasi politik langsung, melainkan dengan jalan perang saraf budaya melalui radio komunitasnya. I nilah yang menjadikan radio komunitas mampu melahirkan 
cikal bakal masyarakat madani di daerah Pantura Jawa Barat.

Bercermin dari fenomena radio komunitas di daerah Pantura yang memberikan peran strategis bagi peningkatan kualitas hidup masyarakat, maka keberadaan dan keberlangsungan radio komunitas mesti ditumbuhkembangkan di berbagai daerah di Indonesia, karena akan melahirkan masyarakatmasyarakat yang cerdas dan mandiri. Untuk itu, dukungan dari berbagai pihak sangat berarti bagi radio komunitas, terutama dukungan pihak berwenang dan pembuat kebijakan yang harus membuka ruang kesempatan yang lebih luas, salah satunya dengan regulasi yang berpihak pada pengembangan radio komunitas itu sendiri. Bukan malah mengebirinya. Agaknya paradigma berpikir penguasa juga harus mulai berubah dan beralih dengan mengakui peran strategis radio komunitas dalam masyarakat. Untuk pada akhirnya, menjadikan radio komunitas atau media komunitas umumnya, bukan sebagai lawan penguasa, melainkan kawan penguasa dalam membangun bangsa.

\section{Daftar Pustaka}

Abda, Iman (ed). (2008) Radio Komunitas Indonesia: Dari Gagasan \& Potret Lapangan. Bandung: JRKI.

Azarya, Victor. (2000) Community. Kuper, Adam \& Kuper, Jessica. Ensiklopedi Ilmu-IImu Sosial, hal 145-147. Terjemahan Haris Munandar dkk. Jakarta: PT Raja Grafindo Persada.

Hancock, Dawson R. \& Algozzine, Bob. (2006) Doing Case Study Research: Practical Guide for Beginning Researchers. New York: Teachers College Press, Columbia University.

Hardiman, F. Budi. (2009) Kritik Ideologi: Pertautan Pengetahuan dan Kepentingan. Yogyakarta: Kanisius.

Haryanto, Ignatius \& Ramdojo, Juventius Judy. (2009) Dinamika Radio Komunitas. Jakarta: LSPP \& Yayasan Tifa.
Jurriëns, Edwin. (2003) "Radio Komunitas di Indonesia: 'New Brechtian Theatre' di Era Reformasi?". Jurnal ANTROPOLOGI INDONESIA 72, hal.116-130.

Hakam, Ulil. (2011). "Konvergensi Media Dalam Radio Komunitas." Jurnal Penelitian IPTEK-KOM, Volume 13, No. 1, Juni 2011, hal. 67-86.

Kumar, Krishan. (2000) Civil Society. Kuper, Adam \& Kuper, Jessica. Ensiklopedi IImu-IImu Sosial, hal. 113-115. Terjemahan Haris Munandar dkk. Jakarta: PT Raja Grafindo Persada.

Marris, Peter. (2000). Community Development. Kuper, Adam \& Kuper, Jessica. Ensiklopedi Ilmu-IImu Sosial, hal. 147-149. Terjemahan Haris Munandar dkk. Jakarta: PT Raja Grafindo Persada.

Mulyawan, Rahman. (2012). “Penguatan 'Civic Governance' melalui Partisipasi Masyarakat dalam Proses Penyelenggaraan Pemerintah". Jurnal MIMBAR, Vol. 28, No. 2 (Desember, 2012): 157-162. http://ejournal.unisba.ac.id/ index.php/mimbar.

Pawito \& Kartono, Drajat Tri. (2013). "Konstruksi Identitas Kultural Masyarakat Pluralis dalam Terpaan Globalisasi". Jurnal MIMBAR, Vol. 29, No. 1 (J uni, 2013): 111-120. http://ejournal. unisba.ac.id/index.php/mimbar

Rachmiatie, Atie, Sidik, Asep Ahmad \& Parihat. (2007). "Proses Sosialisasi Informasi Agama Islam melalui Media Komunitas sebagai Pembentuk Moralitas Remaja Muslim". Jurnal Mimbar, Vol. XXIII No. 1 Januari-Maret 2007: 121-156. http://ejournal.unisba.ac.id/ index.php/mimbar

Undang-Undang Republik Indonesia Nomor 32 Tahun 2002 tentang Penyiaran.

h t t p : / / para madina.ac.id/ index.php?option $=$ com_content\&view $=$ article\& id=621: memberdayakan-komunitas-lewatradio\&catid $=46:$ berita \&Itemid $=116 \&$ lang $=$ in

http://dishubkominfo.indramayukab.go.id/bidangkominfo/63-data-radio.html 